\title{
First Report of Mycoplasma conjunctivae from Wild Caprinae with Infectious Keratoconjunctivitis in the Pyrenees (NE Spain)
}

\author{
Ignasi Marco, ${ }^{1,4}$ Gregorio Mentaberre, ${ }^{1}$ Cristina Ballesteros, ${ }^{2}$ Daniela F. Bischof, ${ }^{3}$ Santiago Lavín, ${ }^{1}$ and \\ Edy M. Vilei ${ }^{3}{ }^{1}$ Servei d'Ecopatologia de Fauna Salvatge, Facultat de Veterinària, Universitat Autònoma de \\ Barcelona, 08193-Bellaterra, Barcelona, Spain; ${ }^{2}$ Vallcalent Wildlife Rescue Center, Camí de Vallcalent, 25007- \\ Lleida, Barcelona, Spain; ${ }^{3}$ Institute of Veterinary Bacteriology, Vetsuisse Faculty, University of Bern, Länggass- \\ Strasse 122, PO Box, CH-3001 Bern, Switzerland; ${ }^{4}$ Corresponding author (email: Ignasi.Marco@uab.es)
}

ABSTRACT: Frequent outbreaks of infectious keratoconjunctivitis have been reported in wild Caprinae in Europe. While etiologic studies in the Alps indicate that the main etiologic agent is Mycoplasma conjunctivae, there are few reports from other mountain areas, such as the Pyrenees, where $M$. conjunctivae has never been reported. In 2006 and 2007, five adult Pyrenean chamois (Rupicapra pyrenaica; two males and three females) and one adult male European mouflon (Ovis orientalis musimon) were studied; they exhibited clinical symptoms of infectious keratoconjunctivitis such as blindness, corneal opacity, and ulceration. In three of the five chamois tested, and in the mouflon, Mycoplasma conjunctivae was identified from conjunctival swabs by means of a TaqMan ${ }^{\circledR}$ polymerase chain reaction based on the lipoprotein gene $\operatorname{lp} p S$. Cluster analysis indicated that the three southern chamois isolates form a cluster that is distinct from the mouflon isolate. This is the first report of $M$. conjunctivae in Pyrenean chamois, and it supports the hypothesis that $M$. conjunctivae also could be the main cause of infectious keratoconjunctivitis in areas other than the Alps, such as the Pyrenees.

Key words: European mouflon, infectious keratoconjunctivitis, Mycoplasma conjunctivae, Ovis orientalis musimon, Pyrenean chamois, Rupicapra pyrenaica.

Infectious keratoconjunctivitis is a common ocular infection of domestic sheep and goats, but it also occurs frequently in wild Caprinae such as Alpine chamois (Rupicapra rupicapra), Alpine ibex (Capra ibex), European mouflon (Ovis orientalis musimon), and Himalayan tahr (Hemitragus jemlahicus; Giacometti et al., 2002). The disease has been known in the Alps since 1916, when the first outbreak in an Alpine chamois was described (Giacometti et al., 2002). It is characterized by localized inflammation of the conjunctiva and cornea, often leading to blindness and death of the animals due to starvation or falling from cliffs. According to most studies, the most common etiologic agent of the disease in both domestic and wild Caprinae is Mycoplasma conjunctivae (Giacometti et al., 1999; Baker, 2001; Motha et al., 2003; Tschopp et al., 2005; Vilei et al., 2007).

In the Pyrenees, infectious keratoconjunctivitis was first described in 1980 in the Pyrenean chamois (Rupicapra pyrenaica) in France (Catusse, 1982; Tournut et al., 1985). However, the disease had been previously observed in the Spanish Pyrenees in 1952 and in the Cantabrian Mountains (northern Spain) in 1979, as was reported years later (Sánchez-Belda and Martínez-Ferrando, 1985). Since then, several outbreaks have affected this species in the Pyrenees (Pluye, 1986) but the presence of $M$. conjunctivae has not been reported. In 1982, Blanco et al. identified Chlamydia psittaci from one of two Pyrenean chamois that had clinical symptoms consistent with infectious keratoconjunctivitis and suggested that it could be the single cause of the disease in the Spanish Pyrenees. In 1990, an outbreak of the disease occurred in the central Pyrenees but the etiologic agent was not identified (Marco et al., 1992).

Monitoring this disease in wild Caprinae is difficult and costly, and consequently, morbidity and mortality rates are often unknown. In the outbreak affecting the five adult Pyrenean chamois (two males and three females) included in this study, the estimated mortality was low but morbidity may have been very high, based on observations during annual census and the frequent observation of lesions of chamois shot during the hunting season. 
The five affected animals were captured between 2006 and 2007 at the National Hunting Reserve of Alt Pallars-Aran (central Pyrenees, Catalonia, NE Spain, $42^{\circ} 42^{\prime} \mathrm{N}, 0^{\circ} 48^{\prime} \mathrm{E}$ ). Low mortality and high morbidity rates agree with the described impact of infectious keratoconjunctivitis in wild Caprinae, which is generally low $(<5 \%)$, but mortality as high as $30 \%$ has been reported (Giacometti et al., 2002). While infectious keratoconjunctivitis is very common in Alpine chamois and Alpine ibex, it occurs less frequently in mouflon; only two outbreaks have been reported in France from two small populations (Sarrazin et al., 1990; Cugnasse, 1997), and one experimental infection has been performed (Terrier, 1998). The affected adult male European mouflon in our study, captured in November 2006 at the National Freser-Setcases Hunting Reserve (eastern Pyrenees, Catalonia, $\mathrm{NE}$ Spain, $42^{\circ} 23^{\prime} \mathrm{N}, 2^{\circ} 09^{\prime} \mathrm{E}$ ), was the only case of disease reported in this area. However, additional animals could have been affected but were not identified or recorded.

All six animals studied showed emaciation and severe clinical signs of bilateral infectious keratoconjunctivitis including complete blindness, corneal opacity, and ulceration. Animals were hand-captured and transferred to a wildlife rescue center; due to the severity of eye lesions and general bad condition, they were humanely euthanized with an intravenous injection of sodium pentobarbital. Conjunctival swabs were taken from behind the third eyelid, dipped in tubes without transport medium, and stored at $-18 \mathrm{C}$ until analysis at the Institute of Veterinary Bacteriology at the University of Bern, Switzerland. Animals were immediately sent to the Veterinary Faculty of Universitat Autonoma de Barcelona, where necropsy was performed. No significant lesions were observed apart from mild traumatic injuries and those of the eyes.

Although clinical signs and lesions (such as serous or mucopurulent ocular effusion, bilateral corneal opacity, or perforation) are characteristic of infectious keratoconjunctivitis and provide an adequate diagnosis when affected animals are observed in a defined area over a short period of time (Mayer et al., 1997), a definitive diagnosis must be confirmed by culture or polymerase chain reaction (PCR). Using a conventional method, such as a culture, for detection of $M$. conjunctivae is cumbersome and requires specialized technical experience (Giacometti et al., 2002). A nested PCR based on the 16S rRNA gene is available and is reported to be more sensitive than culture, and it does not require special care in the transport of samples (Giacometti et al., 1999). However, nested PCRs are still laborious, and in comparison to conventional PCR, realtime PCR protocols are more rapid (less than $2 \mathrm{hr}$ ) and less laborious, and no postPCR processing of products is required. Thus, we developed a $M$. conjunctivae real-time PCR using an $l p p S$-directed hydrolysis probe on a TaqMan ${ }^{\circledR}$ platform (Applied Biosystems, Foster City, California, USA) (Vilei et al., 2007). The sensitivity of the 16S rRNA-based nested PCR has been reported to be approximately 20 colony forming units (cfu) per PCR reaction (Giacometti et al., 1999). In contrast, the lppS-based TaqMan realtime PCR has a sensitivity of $1-5 \mathrm{cfu}$ in the reaction tube (or $<1,000$ mycoplasmal cells/conjunctival swab). The specificity has been shown to be very high; only $M$. conjunctivae strains were positive, whereas all closely related mycoplasmas tested $(n>100)$ were negative (Vilei et al., 2007). However, it is always possible that there may have been involvement of a yetunknown mycoplasma.

Mycoplasma conjunctivae was detected by TaqMan PCR in three of the five Pyrenean chamois and in the European mouflon with keratoconjunctivitis. These results are consistent with previous reports in Alpine chamois and other wild Caprinae in the Alps, in which $M$. conjunctivae is considered the primary 


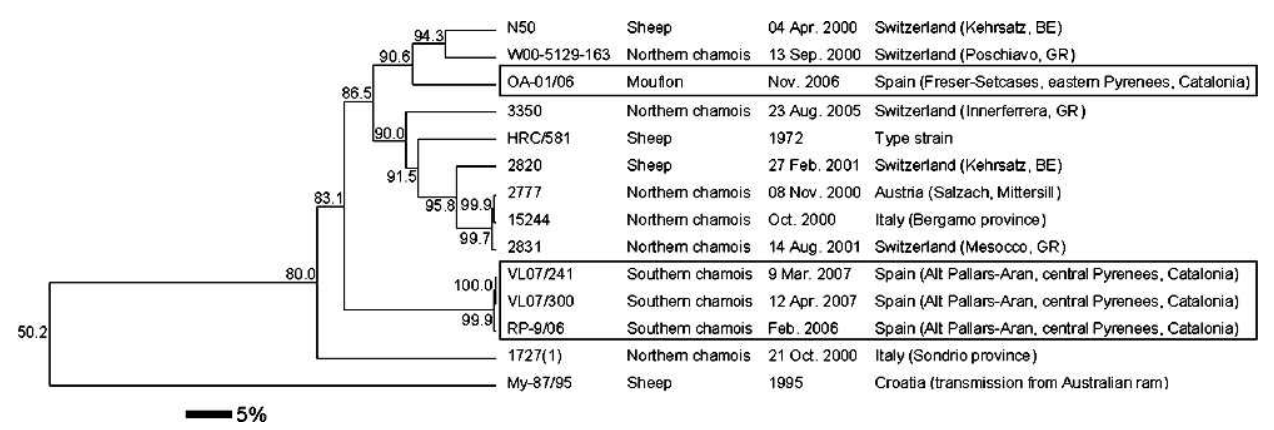

Figure 1. Representation of the phylogenetic relationship of the variable domain of the $\operatorname{lpp} S$ gene of the four Spanish Mycoplasma conjunctivae isolates analyzed (in boxes) and of some isolates already analyzed by Belloy et al. (2003); this was done using the program BioNumerics 5.1 (Applied Maths, Kortrijk, Belgium). Distance matrix was calculated by the Jukes-Cantor algorithm (Jukes and Cantor, 1969), and the cluster analysis tree was built by the UPGMA method (Sneath and Sokal, 1973). Bootstrap values of 500 simulations are indicated at branchings. The scale bar represents the percentage of sequence divergence.

cause of infectious keratoconjunctivitis (Giacometti et al., 2002; Vilei et al., 2007). In two of the five Pyrenean chamois with apparent infectious keratoconjunctivitis, no $M$. conjunctivae could be detected, possibly due to problems with storage of samples prior to analysis, bacterial cross-contamination in the later stages of the disease, or the fact that other pathogens such as Moraxella (Branhamella) ovis, Listeria monocytogenes, or Chlamydia psittaci may have caused the keratoconjunctivitis (Akerstedt and Hofshagen, 2004).

Previous molecular epidemiologic studies of the variable domain of $\operatorname{lpp} S$ have shown that the same strain of $M$. conjunctivae can be isolated from several Caprinae grazing on the same alpine pastures (Belloy et al., 2003). To investigate whether or not the same situation could happen in our study area, we performed a cluster analysis of $\operatorname{lppS}$ DNA from our four TaqMan-positive isolates. Results indicated that the three chamois from the central Pyrenees (where for the last $4 \mathrm{yr}$ there has been relatively constant mortality due to infectious keratoconjunctivitis, with a significant impact on the population) carried mycoplasmas that formed a distinct cluster that did not include the mouflon isolate (Fig. 1). In this respect, it has to be noted that the mouflon comes from the eastern Pyrenees. Chamois have also been affected in that area, but very few cases were observed and with apparently no mortality. These findings raise the question of whether or not the two distinct mycoplasma clusters identified in this study represent strains of $M$. conjunctivae with different pathogenicity. Further studies are needed to answer this query.

Summarizing, in this study we report the first detection of $M$. conjunctivae in the Pyrenees from two species of wild Caprinae, the Pyrenean chamois and the European mouflon. Since outbreaks of infectious keratoconjunctivitis in chamois occur frequently in the Pyrenees, to attempt to develop methods for controlling the disease further etiologic, epidemiologic, immunologic, and ethologic studies are required in wild Caprinae and domestic ruminants.

We acknowledge the help of the rangers of the Miei Ambient Service of the Conselh Generau d'Aran and the rangers of the Department de Medi Ambient de la Generalitat de Catalunya for the capture of the diseased animals. We also thank M. Giacometti (Stampa, Switzerland) and J. Frey (Bern, Switzerland) for initiating cooperation between Spain and Switzerland. 


\section{LITERATURE CITED}

Akerstedt, J., And M. Hofshagen. 2004. Bacteriological investigation of infectious keratoconjunctivitis in Norwegian sheep. Acta Veterinaria Scandinavica 45: 19-26.

Baker, S. E., J. B. Bashiruddin, R. D. Ayling, and R. A. Nicholas. 2001. Molecular detection of Mycoplasma conjunctivae in English sheep affected by infectious keratoconjunctivitis. Veterinary Record 148: 240-241.

Belloy, L., M. Janovsky, E. M. Vilei, P. Pilo, M. Giacometti, and J. Frey. 2003. Molecular epidemiology of Mycoplasma conjunctivae in Caprinae: Transmission across species in natural outbreaks. Applied and Environmental Microbiology 69: 1913-1919.

Blanco, A., M. A. Marcotegui, I. De Frutos, P. De La Esperanza, and C. Saez. 1982. Queratoconjuntivitis clamidial en el rebeco (Rupicapra rupicapra ssp. pyrenaica). INIA: Serie Ganadera 17: 79-85.

Catusse, M. 1982. Evolution de la kératoconjonctivite en Ariège; septembre 1982. Bulletin Mensuel Office National de la Chasse 64: 26-34.

Cugnasse, J. M. 1997. Lenzootie de Kérato-conjonctivite chez le mouflon méditerranéen (Ovis gmelini musimon) du massif du Caroux-Espinasse (Hérault) à lautomme 1993. Gibier Faune Sauvage 14 (4): 569-584.

Giacometti, M., J. Nicolet, K. E. Johansson, T. Naglic, M. P. Degiorgis, and J. Frey. 1999. Detection and identification of Mycoplasma conjunctivae in infectious keratoconjunctivitis by PCR based on the IGS rRNA gene. Journal of Veterinary Medicine B 46: 173-180.

—, M. Janovsky, L. Belloy, and J. Frey. 2002. Infectious keratoconjunctivitis of ibex, chamois and other Caprinae. Revue Scientifique et Technique Office International des Epizooties 21: 335-345.

Jukes, T. H., and C. R. Cantor. 1969. Evolution of protein molecules. In Mammalian protein metabolism, Vol. 3, H. N. Munro (ed.). Academic Press, New York, New York, pp. 21-132.

Marco, I., S. Lavin, J. Gonzalo, and L. Viñas. 1992. Estudio de un brote de querato-conjuntivitis infecciosa en los rebecos (Rupicapra pyrenaica) del Pirineo leridano. Veterinaria en Praxis 6: 5762

Mayer, D., M.-P. Degiorgis, W. Meier, J. Nicolet, AND M. Giacometti. 1997. Lesions associated with infectious keratoconjunctivitis in alpine ibex. Journal of Wildlife Diseases 33: 413-419.
Motha, M. X. J., J. Frey, M. F. Hansen, R. Jamaludin, and K. M. Tham. 2003. Detection of Mycoplasma conjunctivae in sheep affected with conjunctivitis and infectious keratoconjunctivitis. New Zealand Veterinary Journal 51: 186190.

Pluye, J. F. 1986. Contribution a l'étude de la kératoconjonctivite de l'isard. PhD Dissertation. University of Toulouse, Toulouse, France, 99 pp.

SÁnchez-Belda, A., and J. Martínez-Ferrando. 1985. Contribution au diagnostique de la kérato-conjonctivite du chamois (Rupicapra rupicapra) en Espagne. In Proceedings: Atti del Simposio internazionale sulla cheratocongiuntivite infettiva del camoscio, T. Balbo, P. Lanfranchi, P. G. Meneguz and L. Rossi (eds.). Vercelli-Varallo Sesia, Italy, 1982, pp. 73-78.

Sarrazin, C., J. Oudar, M. Prave, Y. Richard, and J. Borel. 1990. Première description chez le mouflon (Ovis ammon musimon) d'une enzootie de kératoconjonctivite infectieuse survenue dans les Alpes frangaises du Sud. Gibier Faune Sauvage 7: 389-399.

Sneath, P. H. A., and R. R. Sokal. 1973. Numerical taxonomy. The principles and practice of numerical classification. W. H. Freeman and Company, San Francisco, California, 73 pp.

Terrier, M. E. 1998. La kératoconjonctivite des ongulés sauvages de montagne. Reproduction expérimentale chez le mouflon (Ovis gmelini musimon). PhD Dissertation, University Claude Bernard of Lyon, Lyon, France, 144 pp.

Tournut, J., R. Lautie, F. Geral, J. P. Alzieu, and J. P. Pluye. 1985. Observations et recherche sur la kératoconjonctivite des isards. In Proceedings: Atti del Simposio internazionale sulla cheratocongiuntivite infettiva del camoscio, T. Balbo, P. Lanfranchi, P. G. Meneguz and L. Rossi (eds.). Vercelli-Varallo Sesia, Italy, 1982, pp. 41-52.

Tschopp, R., J. Frey, L. Zimmermann, and M. GiacometTi. 2005. Outbreaks of infectious keratoconjunctivitis in alpine chamois and ibex in Switzerland between 2001 and 2003. Veterinary Record 157: 13-18.

Vilei, E. M., L. Bonvin-Klotz, L. Zimmermann, M.-P. Ryser-Degiongis, M. Giacometti, and J. FreY. 2007. Validation and diagnostic efficacy of a TaqMan ${ }^{\circledR}$ real-time PCR for the detection of Mycoplasma conjunctivae in the eyes of infected Caprinae. Journal of Microbiological Methods 70: 384-386.

Received for publication 23 January 2008. 